\title{
Laparoscopic Diverting Sigmoid Loop Colostomy for Rectovesical Fistüla: A Video Vignette
}

\section{Rektovezikal Fistül için Laparoskopik Saptırıcı Sigmoid Loop Kolostomi: Video Sunum}

\author{
(1) Feyyaz Güngör, (1) Erdinç Kamer, (1) Yiğit Atalay, @ Mustafa Peskersoy \\ İzmir Katip Çelebi University, Atatürk Training and Research Hospital, Clinic of General Surgery, İzmir, Turkey
}

\section{HIIIIII| ABSTRACT}

Ileostomy and colostomy procedures are useful in treating patients suffering from complications associated with intra-abdominal diseases, complicated infections, faecal incontinence, rectovesical fistula, perianal fistula, perianal Crohn's disease, radiation proctitis or advanced colorectal cancers. In recent decades, laparoscopic stoma formation is gaining popularity as an alternative to conventional open abdominal surgery. Conventional surgery is associated with a higher rate of morbidity and mortality. Trephine colostomy technique has the disadvantage that it does not allow exploration and is inadequate to detect proximal and distal bowel loops, and the immobilised sigmoid colon does not allow mobilisation of the bowel. Because of these disadvantages laparoscopic ostomy technique is a better choice in patients who are found to be suitable.

In this video, we present a patient who underwent laparoscopic loop sigmoid colostomy for rectovesical fistula.

Keywords: Laparoscopic, loop colostomy, rectovesical fistula

\section{IIIIIIIII ÖZ}

İleostomi ve kolostomi; abdominal patolojiler, komplike enfeksiyonlar, fekal inkontinas, rektovezikal fistül, perianal fistül, perineal Chron hastalığı, radyasyon proktiti ve ileri kolorektal kanserler ile ilgili komplikasyonları olan hastalarda terapötik faydaları vardır. Konvensiyonel cerrahi daha fazla morbidite ve mortalite ile ilişkilidir. Trephine kolostomi tekniğinin eksprolasyona izin vermemesi, proksimal ve distal barsak anslarının belirlenmesinde yetersiz olması ve immobil sigmoid kolonun mobilizasyona izin vermemesi gibi dezavantajları vardır. Bu dezavantajlar nedeniyle laparoskopik ostomi tekniği uygun hastalarda daha iyi bir tercihdir. Bu videoda; rektovezikal fistül nedeniyle laparoskopik saptırıcı sigmoid loop kolostomi açılan bir olguyu sunuyoruz.

Anahtar Kelimeler: Laparoskopik, loop kolostomi, rektovezikal fistül

\section{Introduction}

Ileostomy and colostomy procedures are useful in treating patients with complications related to intra-abdominal diseases, complicated infections, faecal incontinence, rectovesical fistula, perianal fistula, perineal Crohn's disease, radiation proctitis or advanced colorectal cancers. In recent decades, laparoscopic stoma formation is gaining popularity as an alternative to conventional open abdominal surgery. ${ }^{1}$ Conventional surgery is associated with a higher rate of morbidity and mortality. Trephine colostomy technique has the disadvantage that it does not allow exploration, is inadequate to determine proximal and distal bowel loops, and the immobilised sigmoid colon does not allow mobilisation of the bowel. ${ }^{2}$ Because of these disadvantages laparoscopic ostomy technique might be a better choice in suitable patients. In this video, we present a patient who underwent laparoscopic loop sigmoid colostomy for rectovesical fistula. Informed consent was obtained from the patient. In the

Address for Correspondence/Yazışma Adresi: Feyyaz Güngör, MD, 
preoperative period, the patient met with stoma nurses to mark the stoma site and to receive information about stoma care and management.

During the procedure, a pneumoperitoneum was created, an $11 \mathrm{~mm}$ trocar was placed over the umbilicus and a $5 \mathrm{~mm}$ trocar was placed lateral to the right rectus muscle. No other intraperitoneal pathology was detected during exploration. The sigmoid colon was found to be mobile. Afferent and efferent bowel loops were identified. A circular incision was made on the skin at the previously marked stoma site and excised. The anterior fascia of the musculus rectus abdominis was opened diagonally, and after the muscle fibres were separated with a retractor, the posterior fascia, preperitoneal cavity and peritoneum were passed and the abdominal cavity was entered. The sigmoid colon was taken out of the abdomen and the afferent and efferent loops were re-evaluated, and the laparoscopy was terminated. A window was created for loop colostomy in the mesocolon. Following this, ostomy maturation was achieved in the standard manner with Vicryl suture.

In conclusion, our case demonstrates that laparoscopic loop sigmoid colostomy is a better choice than conventional methods in certain patients who are considered suitable.
Informed Consent: Informed consent was obtained from the patient.

Peer-review: Externally peer reviewed.

\section{Authorship Contributions}

Surgical and Medical Practices: F.G., E.K., Concept: F.G., E.K., Y.A., M.P., Design: E.K., M.P., Data Collection or Processing: F.G., Y.A., M.P., Analysis or Interpretation: E.K., M.P., Literature Search: F.G., E.K., M.P., Writing: F.G., E.K., M.P.

Conflict of Interest: No conflict of interest was declared by the authors.

Financial Disclosure: The authors declared that this study received no financial support.

\section{References}

1. Ansell J, Hughes D, Torkington J. Laparoscopic Ileostomy and Colostomy for Faecal Diversion. In: Parker $M$, Hohenberger $W$, eds. Lower Gastrointestinal Tract Surgery: Vol.1, Laparocpoic procedures. Springer Surgery Atlas Series. Springer, Cham. 2019:541-552

2. Kamer E, Cengiz F, Er A, et al. Trephine Colostomy: Minimally Invasive Stoma Techniqu. British Journal of Medicine \& Medical Research 2016;15(7):1-4

\section{Video 2.}

